\title{
BEST PRACTICE PENGGUNAAN GOOGLE CLASSROOM DAN WHATSAPP GROUP SEBAGAI MEDIA PEMBELAJARAN JARAK JAUH SENI BUDAYA
}

\author{
CHUCIK UBAIDAH \\ SMP Negeri 7 Batang \\ J1. Tentara Pelajar No.20 Kalisalak Batang - Jawa Tengah \\ chucikubaidah@gmail.com
}

\begin{abstract}
ABSTRAK
Penelitian ini bertujuan untuk mendeskripsikan proses Pembelajaran Jarak Jauh (PJJ) mata pelajaran Seni Budaya di Sekolah SMP Negeri 7 Batang menggunakan aplikasi Google Classroom dan WhatsApp Group sebagai bagian integral dalam googledrive. Aplikasi ini digunakan dalam membantu menggali informasi dan media dalam Pembelajaran Jarak Jauh (PJJ) non tatap muka. Google Classroom dan WhatsApp Group diterapkan sebagai salah satu media PJJ pada masa pandemi corona virus disease 2019 (Covid-19) yang sedang melanda tanah air bahkan dunia internasional. Penelitian dilaksanakan melalui tahapan perencanaan, pelaksanaan, pengamatan, dan refleksi. Pengumpulan data dilakukan dengan cara a) Observasi b) Wawancara, c) Tes Praktek. Adapun jenis instrumen yang digunakan diantaranya: a) lembar pengamatan, b) pedoman wawancara, c) lembar penilaian tes praktek. Hasil penelitian ini diperoleh data sebanyak 87\% menggunakan Google Classroom dan 98\% menggunakan WhatsApp Group dapat diperoleh dirata-rata dari penggunaan dua aplikasi tersebut sebanyak 92,5 \% siswa dari 8 kelas dalam PJJ. Dengan demikian bahwa penggunaan media Google Classroom dan WhatsApp Group terbukti dapat meningkatkan belajar seni budaya dalam PJJ. Hal ini dibuktikan dengan menunjukkan bahwa hasil penggunaan media Google Classroom dan WhatsApp Group selalu meningkat.
\end{abstract}

Kata Kunci : Google Classroom, WhatsApp Group, Media, Pembelajaran Jarak jauh (PJJ)

\section{PENDAHULUAN}

Semenjak diberlakukannya masa darurat Covid-19 pada tanggal 16 Maret 2020, hampir seluruh sekolah di Indonesia terutama di Jawa Tengah mengambil kebijakan untuk pembelajaran via daring atau disebut dengan Pembelajaran Jarak Jauh (PJJ). Dengan adanya pembelajaran daring guru dan siswa sama-sama belajar untuk memanfaatkan teknologi sebagai media pembelajaran. Dengan diberlakukannya pembelajaran di rumah yang terkesan mendadak, membuat hampir semua kepala sekolah dan guru-guru memutar otak untuk mencari cara atau strategi yang tepat dalam pemberian tugas kepada para siswanya. Termasuk sekolah kami, karena pada awalnya masa belajar di rumah hanya berlaku untuk 2 pekan saja, maka berdasarkan arahan bagian kurikulum dan kesiswaan serta melihat kondisi dan latar belakang siswa dan orang tua yang sangat beragam maka siswa diberikan tugas dari bapak ibu guru mata pelajaran melalui wali kelasnya masing-masing di kelas pada 
hari pertama berlakunya belajar di rumah. Sehingga pada hari pertama belajar di rumah siswa kami masih berangkat ke sekolah untuk menerima informasi mengenai pandemi Corona Covid 19 dan alasan mengapa KBM dialihkan di rumah.

Pelaksanaan penyelenggara kegiatan di sekolah perlu dimonitoring dan dievaluasi keberlangsungannya agar terhindar dari hal hal yang berdampak negarif berkepanjangan. Pihak sekolah, pemerintah, dan masyarakat terus berupaya untuk melakukan persiapan dan pemenuhan persyaratan penyelenggaraan pembelajaran tatap muka terbatas sesuai ketentuan berlaku pada zona hijau dan kuning. Penilaian tersebut merupakan bagian yang sangat penting dalam pembelajaran dan pengajaran. Jika pada aspek pembelajaran mempunyai peran penting mengembangkan aspek sikap, pengetahuan dan keterampilan siswa, maka fungsi media sebagai penyedia informasi untuk menilai kesuksesan belajar sangat dibutuhkan. Media pembelajaran merupakan alat bantu pada proses belajar baik di dalam kelas maupun di luar kelas, lebih lanjut dijelaskan bahwa media pembelajaran merupakan komponen sumber belajar atau wahana fisik yang mengandung materi instruksional di lingkungan siswa yang dapat merangsang siswa untuk belajar. (Azhar, 2011).

Pada awal Pembelajaran Jarak Jauh mapel seni budaya di SMP Negeri 7 Batang hanya menggunakan aplikasi WhatsApp Group Zoom Meeting, akan tetapi guru kesusahan dalam pengiriman tugas, apalagi sebagian besar materi dari mata pelajaran Seni Budaya menggunakan praktek dan harus dalam bentuk video yang berdurasi panjang. Selain itu pada saat siswa ketinggalan mengikuti pembahasan di WhatsApp Group maka siswa ataupun guru harus menyecroll ke atas untuk mencari pembahasan tadi dan tugas-tugas siswa tidak terekap secara jelas.

Rendahnya penggunaan media untuk PJJ tidak diatasi, maka dampak kepada siswa kkm tidak tercapai sehingga anak menjadi tidak akan naik kelas, hal tersebut juga akan meyangkut kinerja guru (kurang optimal), yang akan berpengaruh terhadap citra/nama baik sekolah. Untuk mengatasi rendahnya penggunaan media untuk PJJ, maka salah satu upaya guru yaitu dengan menggunakan media pembelajaran Google Classroom dan WhatsApp Group. Pemilihan media pembelajaran Google Classroom dan WhatsApp Group dalam pembelajaran di kelas karena media pembelajaran Google Classroom dan WhatsApp Group merupakan salah satu cara untuk membuat pembelajaran lebih dinamis dan menyenangkan karena media Google Classroom dan WhatsApp Group adalah media yang mempermudah siswa untuk menerima materi dan mengirim tugas-tugasnya.

Sejalan hal tersebut peranan aplikasi Google Classroom sangat membantu guru. Adanya perubahan pola masyarakat dalam mengonsumsi berita seiring dengan kemajuan teknologi yang memberikan dampak besar. Misalnya mereka lebih senang membaca berita lewat kanal pribadi di media sosial salah satunya WhatsApp Group. (Bafadhal, 2020) Dalam hal ini media yang paling sering digunakan dan lebih populer pada sekolah kami untuk mewadahi proses media berjalan digunakan Google Classroom dan WhatsApp Group.

Tujuan dari penelitian ini untuk mendeskripsikan proses Pembelajaran Jarak Jauh (PJJ) mata pelajaran Seni Budaya di Sekolah SMP Negeri 7 Batang menggunakan aplikasi Google Classroom dan WhatsApp Group sebagai bagian integral dalam googledrive. Pada artikel ini, penulis akan mendeskripsikan hasil data 
empiris tentang Google Classroom dan WhatsApp Group sebagai aplikasi yang digunakan untuk media PJJ seni budaya di SMP Negeri 7 Batang. Peranan aplikasi ini sangat membantu mengelola informasi terkait pembelajaran jarak jauh yang di laksanakan di SMP Negeri 7 Batang selama pandemi covid-19 dengan judul: Best Practice Google Classroom dan WhatsApp Group Sebagai Media PJJ Seni Budaya

\section{METODE PENELITIAN}

Metode Penelitian artikel ini menggunakan analisis deskriptif. Teknik pengumpulan data melalui angket, wawancara, observasi, dan studi dokumentasi. Waktu Penelitian mulai bulan Juli sampai dengan Agustus 2020. Objek penelitian penulisan ini siswa di SMP Negeri 7 Batang. Populasi penelitian sejumlah 8 kelas, karena peneliti mengajar di kelas tersebut. Metode penelitian deskriptif dan metode angket digunakan untuk mengetahui dan mempelajari data dari sampel yang diambil dari populasi. Dengan metode ini diperoleh data atau informasi kejadian-kejadian relatif, distribusi, serta hubungan-hubungan antar variable.(Sugiyono, 2016)

Tahapan penelitian penulis mendeskripsikan Google Classroom dan WhatsApp Group Sebagai Media PJJ Seni Budaya di SMP Negeri 7 Batang melalui tiga tahapan. Tahapan tersebut: Pertama, tahap perencanaan dimulai pada pertengahan bulan Juli 2020. Tujuannya mengidentifikasi rumusan permasalahan yang diperoleh dalam kegiatan Pembelajaran Jarak Jauh di sekolah kami. Kedua, tahap pelaksanaan yang selanjutnya dicari beberapa alternatif solusi menjawab rumusan masalah. Media tertentu yang biasa digunakan mapel seni budaya di SMP Negeri 7 Batang yaitu aplikasi Google Classroom dan WhatsApp Group. Hal ini sejalan dengan pemikiran jika pertanyaan yang muncul atas masalah yang ada maka perlu dijawab, dan dikaji secara ilmiah (Muri Yusuf, 2017). Hasil penggalian data menggunakan survey atau angket, wawancara, studi dokumentasi dan observasi. Ketiga, tahap evaluasi dan kesimpulan.

Google Classroom dan WhatsApp Group merupakan salah satu alternatif solusi yang digunakan. Sebagai seorang guru yang telah mengajar 16 tahun, sudah paham bahwa siswa memiliki berbagai keterbatasan. Google Kelas (bahasa Inggris: Google Classroom) adalah layanan web gratis, yang dikembangkan oleh Google untuk sekolah, yang bertujuan untuk menyederhanakan membuat, mendistribusikan, dan menilai tugas tanpa harus bertatap muka. Tujuan utama Google Classroom adalah untuk merampingkan proses berbagi file antara guru dan siswa.(Wikipedia Bahasa Indonesia). WhatsApp Group adalah aplikasi pesan untuk ponsel cerdas. WhatsApp Messenger merupakan aplikasi pesan lintas platform yang memungkinkan kita bertukar pesan tanpa pulsa, karena WhatsApp Messenger menggunakan paket data internet. (Wikipedia Bahasa Indonesia).

Data inti diperoleh selama penelitian, dari hasil penelitian diperoleh data verbal yaitu data yang dipeoleh peneliti selama observasi. Dalam data ini peneliti mencatat penggunaan aplikasi siswa dan guru selama penelitian berlangsung. Dari tampilan data verbal peneliti memperoleh hasil refleksi yang didukung oleh siswa, orangtua dan guru yaitu berupa kelemahan-kelemahan serta hambatan yang ditemukan yang selanjutnya dipakai sebagai dasar perbaikan selama PJJ. 


\section{HASIL DAN PEMBAHASAN}

Pembelajaran pada masa pandemi corona virus disease 2019 sudah berlangsung sejak bulan Maret 2020 memberikan dampak yang luas dalam kehidupan dunia, salah satunya berdampak pada dunia Pendidikan. Proses pembelajaran tatap muka yang biasa dilakukan di kelas sudah beralih dengan kegiatan PJJ atau belajar dari rumah (BDR). Dengan kebijakan Kemendikbud penggunaan relaksasi kurikulum 2013, kurikulum darurat atau yang disederhanakan mandiri oleh satuan pendidikan.

Kondisi awal pada saat PJJ hanya menggunakan aplikasi WhatsApp Group saja, pada waktu itu masih binggung harus mencari media yang tepat untuk PJJ terutama pada mapel Seni Budaya yang mayoritas materinya menggunakan praktek. Di bawah ini gambar WhatsApp Group kelas sebanyak 8 kelas :
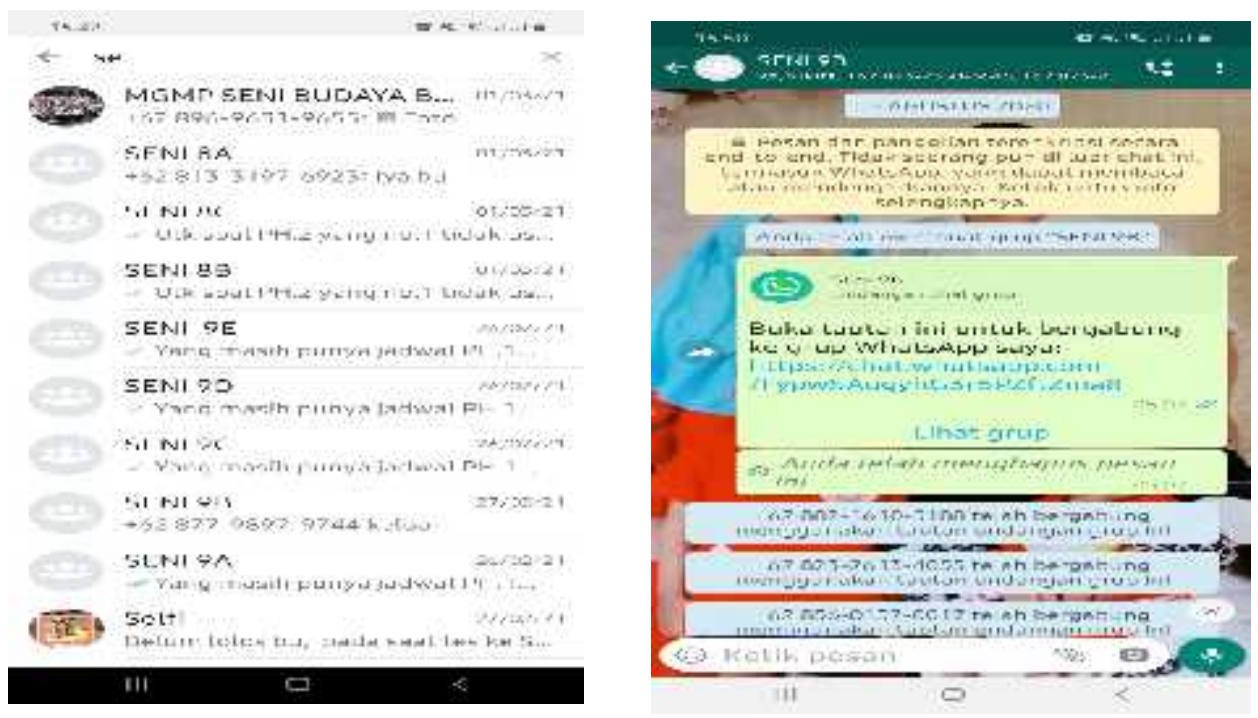

Gambar 1 : WhatsApp Group (Dokumentasi : 2020)

Keberhasilan pembelajaran sangat tergantung kepada kemampuan guru dalam mengelola pembelajaran. Guru merupakan ujung tombak paling depan dalam mewujudkan keberhasilan penyelenggaraan pembelajaran dan pendidkan pada tingkat satuan pendidikan. Salah satunya kemampuan guru dalam menggunakan media pembelajaran Google Classroom dan WhatsApp Group.

Google Classroom menggabungkan Google Drive untuk pembuatan dan pengiriman penugasan, Google Docs, Sheets, dan Slides untuk penulisan, Gmail untuk komunikasi, dan Google Calendar untuk penjadwalan. Siswa dapat diundang untuk bergabung dengan kelas melalui kode pribadi, atau secara otomatis diimpor dari domain sekolah. Setiap kelas membuat folder terpisah di Drive masing-masing pengguna, di mana siswa dapat mengirimkan pekerjaan untuk dinilai oleh guru. Mengapa menggunakan Google Classroom untuk memberikan materi dan tugas?.Hal ini dilakukan karena peneliti mengajar pada 8 kelas yang terdiri dari kelas 9 sebanyak 5 kelas dan kelas 8 sebanyak 3 kelas, yang saya didik sebagian dari mereka telah memiliki HP. Jadi saya berusaha untuk memanfaatkan hal tersebut dan agar mereka mendapatkan ilmu baru. 
Google Classroom (Ruang Kelas Google) adalah suatu serambi aplikasi pembelajaran campuran secara online yang dapat digunakan secara gratis. Pendidik bisa membuat kelas mereka sendiri dan membagikan kode kelas tersebut atau mengundang para siswanya. Google Classroom ini diperuntukkan untuk membantu semua ruang lingkup pendidikan yang membantu siswa untuk menemukan atau mengatasi kesulitan pembelajaran, membagikan pelajaran dan membuat tugas tanpa harus hadir ke kelas. Tujuan utama Google Classroom adalah untuk merampingkan proses berbagi file antara guru dan siswa Google Classroom menggabungkan Google Drive untuk pembuatan dan distribusi penugasan, Google Docs, Sheets, Slides untuk penulisan, Gmail untuk komunikasi, dan Google Calendar untuk penjadwalan. Siswa dapat diundang untuk bergabung dengan kelas melalui kode pribadi, atau secara otomatis diimpor dari domain sekolah.

Google Classroom bagi siswa sangat memudahkan karena siswa bisa menerima materi dalam bentuk file apapun dan di Google Classroom siswa dengan mudah dalam mencari tugas dengan melihat di sheet "Tugas" apabila siswa ketinggalan dalam mengikuti pembelajaran. Tidak perlu scroll ke atas untuk mencari tugas yang belum dikerjakan oleh siswa. Selain itu bagi guru sangat memudahkan dalam memonitoring absen, tugas-tugas siswa yang belum menyerahkan dan belum sesuai dengan perintah soalnya dan bisa mendapatkan data nilai siswa.

Fitur- fitur yang sangat menunjang pembelajaran online ini yang ada di Google Classroom antara lain :

\section{Tugas (Assignments)}

Setiap tugas yang diunduh akan disimpan dan dinilai pada rangkain aplikasi produktivitas Google yang telah memunkinkan kolaborasi online ini. Daripada hanya berbagi dokumen yang berada di Google Drive siswa dengan guru, file di-host di Drive siswa dan kemudian dikirim untuk dinilai. Guru dapat memilih file sebagai templat sehingga setiap siswa dapat mengedit salinan mereka sendiri dan kemudian kembali untuk mendapatkan nilai sehingga semua siswa bisa melihat, menyalin, atau mengedit dokumen yang sama. Siswa juga dapat memilih untuk melampirkan dokumen tambahan dari Drive mereka ke tugas.

\section{Penilaian (Grading)}

Google Classroom mendukung banyak cara penilaian yang berbeda. Guru memiliki opsi untuk memantau kemajuan setiap siswa pada tugas di mana mereka dapat membuat komentar dan mengedit. Tugas yang diubah dapat dinilai oleh guru dan dikembalikan dengan komentar untuk memungkinkan siswa merevisi tugas dan dikembalikan. Setelah dinilai, tugas hanya dapat diedit oleh guru kecuali guru mengembalikan tugas. Meninjau tugas sangat diperlukan, karena kita bisa melihat kesalahan atau kekurangan apa yang masih ada di tugas yang akan kita kirim. Maka Google Classroom menyediakan fitur melihat tugas sebelum dikirim. Seharusnya setiap aplikasi belajar harus memberikan fitur seperti milik Google Classroom tersebut untuk memudahkan dalam peninjauan tugas kita

\section{Komunikasi yang lancar}

Pengumuman dapat diposting oleh guru ke aliran kelas yang dapat dikomentari oleh siswa yang memungkinkan komunikasi dua arah antara guru dan 
siswa. Siswa juga dapat memposting ke kelas tetapi tidak akan setinggi prioritas sebagai pengumuman oleh guru dan dapat dimoderasi. Berbagai jenis media dari produk Google seperti video YouTube dan file Google Drive dapat dilampirkan ke pengumuman dan pos untuk berbagi konten. Gmail juga menyediakan opsi email bagi guru untuk mengirim email ke satu atau lebih siswa di antarmuka Google Classroom. Kelas dapat diakses di web atau melalui aplikasi seluler Kelas Android dan iOS. Selain itu Google Classroom juga mempunyai banyak fitur yang praktis, efisien dan terjamin keamanannya. Kelas pembelajaran akan tetap tersimpan meski secara online, interaksi guru dan siswa juga dapat terjadi dengan baik. Pembelajaran akan terasa lebih mudah mengingat Google Classroom ini juga dapat diakses dimana saja dan kapan saja.

Siswa dan pendidik juga dapat belajar dan mengajar melalui perangkat seluler Android atau iOS mereka. Pembagian materi pembelajaran juga terasa lebih ringkas, pekerjaan siswa dan penilaian juga menjadi lebih transparan. Para siswa juga dapat menyapa dan bekerja sama mengerjakan tugas dengan teman sekelas mereka layaknya di kelas yang sebenarnya. Kelebihan Google Classroom lainnya adalah semua bentuk file baik itu mp4,mp3, doc, pdf,zip dan masih banyak lagi. Semua itu otomatis masuk ke akun Google Drive kita sehingga kita tidak usah mencari penyimpanan yang lain untuk menyimpan file yang telah kita upload. Maka tidak usah khawatir akan kehilangan file ataupun dokumen yang lainnya. Itu semua sudah tersimpan di Google Drive. Di bawah ini gambar Google Classroom kelas sebanyak 8 kelas :
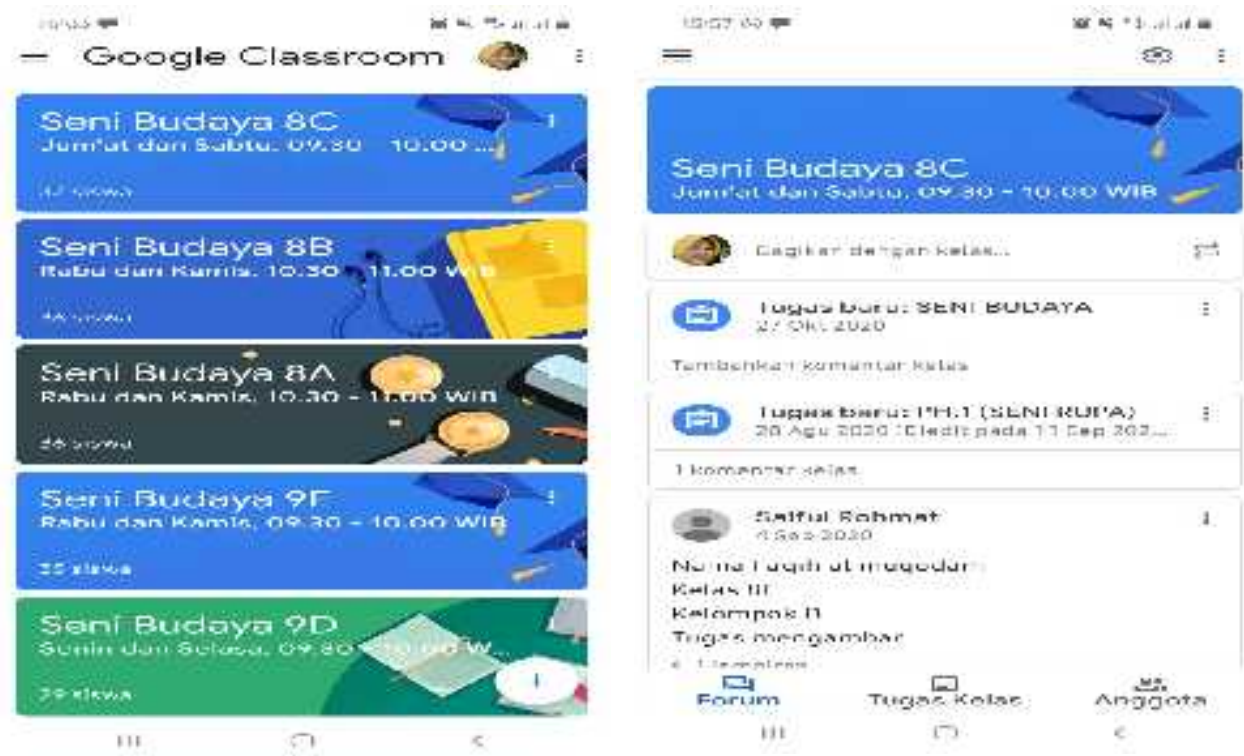

Gambar 2: Google Classroom (Foto Chucik : 2020)

Respon awal hanya $87 \%$ siswa yang bergabung di Google Classroom. Ternyata setelah ada perpanjangan tahap ke 3 belajar di rumah, guru akhirnya menyarankan semua siswa menggunakan aplikasi berbasis online dimana sebagian 
besar siswa menggunakan aplikasi Google Classroom. WhatsApp berupa aplikasi pesan pada smartphone yang berfungsi sama dengan aplikasi sms pada ponsel lama yang cara kerjanya tidak membutuhkan pulsa melainkan dengan sambungan internet. (darmawan D. ) Panjang pendeknya karakter tidak berpengaruh selama data internet memadai, dengan fitur-fitur yang lengkap, antara lain: mengirim langsung foto dari kamera, video, audio, lokasi, kontak, pengelolaan berkas, galeri. WhatsApp sudah dikenal luas potensinya di dunia Pendidikan (Ketut Suardika etal., 2020).

Menurut Larasati, dkk (2013), WhatsApp merupakan aplikasi untuk saling berkirim pesan secara instan, dan memungkinkan kita untuk saling bertukar gambar, video, foto, pesan suara, dan dapat digunakan untuk berbagi informasi dan diskusi. Whatsapp juga dapat digunakan untuk bertukar informasi dan penyebaran informasi. WhatsApp untuk media saling berbagi informasi, saat ini bukanlah suatu hal yang sulit untuk ditemukan. Dengan adanya beragam jenis media sosial, termasuk Whatsapp berbagi informasi menjadi jauh lebih mudah. Jika anda membutuhkan banyak informasi menarik, biasanya pengguna Whatsapp itu sendiri akan banyak yang membagikannya menggunakan fitur story. Kelebihan dari WhatsApp untuk PJJ antara lain :

1. Tidak harus login terlebih dahulu untuk mengakses WhatsApp jika nomor ponsel sudah terdaftar.

2. Langsung terhubung dengan kontak pengguna WhatsApp lainnya.

3. Pengguna dapat bertukar kontak dengan pengguna lainnya.

4. Dapat membagikan lokasi terkini.

5. Dapat mengirim pesan ke banyak orang (broadcast).

6. Aplikasi ini tidak menguras kuota terlalu banyak.

7. Guru dan siswa dapat berdiskusi dan bertanya jawab dengan lebih rileks.

8. Dapat melihat siapa saja yang sudah membaca dan siapa yang tidak aktif.

9. Guru dapat mengirimkan dokumen, foto, audio ataupun video sebagai materi pembelajaran kepada siswa melalui grup WhatsApp.

10. Guru dan siswa dapat melihat dan mengulang materi pembelajaran melalui HP dengan mudah.

11. Guru dan siswa dapat berkomunikasi kapan saja dan di mana saja.

Penggunaan Whatsapp grup siswa dapat berinteraksi dengan teman sekelas dan guru, memberikan komentar, menanggapi komentar yang dikirim oleh orang lain, memposting materi pembelajaran atau link materi pembelajaran, foto, video dan suara ( Suardika et.al : 2020). Teknik aplikasi Wag yang digunakan pada saat PJJ seni budaya di SMP Negeri 7 Batang dengan membuat group kelas yang diatur oleh wali kelas sebagai admin. Guru mata pelajaran memanfaatkan media ini bahkan orang tua dapat mendampingi karena dianggap mudah, ekonomis praktis dan cukup efektif. Penggunaan WhatsApp Group pada saat PJJ untuk mapel seni budaya hanya untuk mengingatkan dan membahas materi yang belum dipahami oleh siswa. Jadi WhatsApp Group tidak untuk memberikan materi, tugas dan tempat untuk pengumpulan tugas-tugas siswa.

Hasil data empiris bahwa penggunaan media sosial seperti Whatsapp Grup lebih banyak digunakan oleh guru dan siswa untuk mapel seni budaya sebanyak $98 \%$ 
dari 8 kelas. Hal ini menjadi alasan penting penulis mengangkat peran Whatsapp Grup dalam PJJ. Media Pembelajaran dapat dipahami sebagai segala sesuatu yang dapat menyampaikan atau menyalurkan pesan dari sumber secara terencana, sehingga terjadi lingkungan belajar yang kondusif dimana penerimanya dapat melakukan proses belajar secara efesien dan efektif (Rayanda,2012). Dalam kegiatan kepengawasan terhadap proses PJJ dimulai dari perencanaan, pelaksanaan dan media pembelajaran menggunakan Google Classroom dan WhatsApp Group. Aplikasi ini digunakan penulis untuk menyesuaikan dengan kondisi SMP Negeri 7 Batang. Pada masa Pandemi covid-19 terbit Keputusan Bersama 4 menteri RI, dengan surat edaran Mendikbud RI nomor 2 dan 3 Tahun 2020 tentang Pembelajaran secara daring (dalam jaringan) dan bekerja dari rumah dalam rangka pencegahan virus coronadisease 2019 masih tetap berlaku bagi zona hijau dan kuning dengan protokol kesehatan dan keselamatan yang ketat.

Untuk media pembelajaran, hasil penelitian secara empiris diperoleh data dari spreadsheet terbanyak sebanyak 87\% menggunakan Google Classroom dan 98\% menggunakan WhatsApp Grup, artinya berdasarkan data empiris bahwa penggunaan aplikasi WhatsApp Group pada pembelajaran jarak jauh mengindikasikan bahwa aplikasi ini paling tinggi atau selalu digunakan dengan menunjukkan hasil terbanyak. Hasil penelitian secara empiris diperoleh data dari spreadsheet terbanyak sebanyak 87\% menggunakan Google Classroom dan 98\% menggunakan WhatsApp Group dapat diperoleh dirata-rata dari penggunaan dua aplikasi tersebut sebanyak $92,5 \%$ siswa dari 8 kelas dalam PJJ.

Gambaran umum dari observasi, studi dokumen, dan pendapat dari hasil wawancara angket diperoleh hasil bahwa Google Classroom dan WhatsApp Group sebagai media PJJ sangat berperan penting dan paling mudah, praktis, efektif, akurat memberikan dampak hasil dalam PJJ. Untuk meningkatkan antusiasme perlu memberikan tambahan alternatif lain. Sebagaimana pembelajaran tatap muka, perlu diberikan penguatan dan motivasi. Agar antusiasme siswa pada aplikasi ini lebih kuat, hendaknya diberi strategi yang tepat, variatif, yang dapat dijangkau oleh semua guru dan siswa pada SMP Negeri 7 Batang. Faktor lainnya dengan memaksimalkan penggunaan fasilitas PJJ, protokol kesehatan dan keselamatan lebih ketat diterapkan sehingga wabah cepat berakhir. Orang tua dalam penggunaan Google Classroom dan WhatsApp Group ini sangat mendukung. Dengan alasan sebagai salah satu aplikasi yang dapat diandalkan. Aplikasi inipun membantu guru melaksanakan media PJJ. Terbukti fungsinya akurat, praktis, dan ekonomis pada masa penggunaan kurikulum darurat pandemi ccovid-19.

Dari paparan data diatas, dapat diketahui terjadinya peningkatan penggunaan media GCRWag untuk mata pelajaran Seni Budaya selama PJJ di SMP Negeri 7 Batang, yang sebelumnya hanya menggunkan aplikasi WhatsApp Group saja. Untuk media pembelajaran, hasil penelitian secara empiris diperoleh data dari spreadsheet terbanyak sebanyak 87\% menggunakan Google Classroom dan 98\% menggunakan WhatsApp Grup, artinya berdasarkan data empiris bahwa penggunaan aplikasi Wag pada pembelajaran jarak jauh mengindikasikan bahwa aplikasi ini paling tinggi atau selalu digunakan dengan menunjukkan hasil terbanyak. Hasil penelitian secara empiris diperoleh data dari spreadsheet terbanyak sebanyak $87 \%$ menggunakan 
Google Classroom dan 98\% menggunakan WhatsApp Grup dapat diperoleh diratarata dari penggunaan dua aplikasi tersebut sebanyak 92,5\% siswa dari 8 kelas dalam PJJ.

Hasil penelitian ini sesuai dengan penelitian yang dilakukan Swita Amallia Hapsari, Heri Pamungkas (2019). Dalam penelitiannya, Swita Amallia Hapsari, Heri Pamungkas menunjukkan adanya keuntungan menggunakan Google Classroom dan memanfaatkan media baru sebagai salah satu cara mempermudah siswa belajar mengajar sangat menjadi nilai yang positif. Terutama waktu yang semakin fleksibel dan membuat beberapa keuntungan lain dapat belajar dimanapun tanpat terbatas hanya saat kelas.

\section{KESIMPULAN}

Google Classroom dan WhatsApp Group merupakan aplikasi yang cukup efektif dan efisien digunakan oleh siswa dalam media PJJ seni budaya di SMP Negeri 7 Batang. Hal ini dapat dilihat dari 92,5\% siswa yang menggunakan Google Classroom dan WhatsApp Group dalam PJJ. Guru perlu keratif dan inovatif memilih aplikasi Google Classroom dan WhatsApp Group sebagai media PJJ agar siswa antusias. Guru harus terampil mengelola aplikasi dengan mengembangkan diri, memiliki motivasi, kepedulian, pelatihan meningkatkan kompetensi di bidang IT. Teknologi tidak dapat menggantikan posisi guru. Kelemahan dalam PJJ banyak terkendala, sinyal, kesediaan fasilitas, faktor ekonomi, sumber daya manusia, sosial, dan budaya, faktor pendidikan masyarakat perlu mendapat perhatian khusus dari berbagai pihak dan pemerintah.

Harapan lainnya dari para orang tua dan guru yang menginginkan kembali pembelajaran tatap muka secara normal karena dirasa pembelajaran online masih belum optimal. Pemerintah, masyarakat, dan pihak sekolah menyikapi PJJ masa pandemi dengan prinsip-prinsip yang lebih sederhana, menyenangkan, berbobot, masif, ekonomis, mudah dan praktis. Perlu adanya penguatan dan kerja sama orang tua dan pihak sekolah yang efektif dalam memberikan layanan strategis baik proses pembelajaran dan evaluasinya terhadap capaian tujuan Pendidikan.

\section{DAFTAR PUSTAKA}

Azhar, Arsyad. 2011. Media Pembelajaran. Jakarta : Rajawali Press.

Bafadhal, O. M. 2020. Jurnal Komunikasi Indonesia (/ journal / 56192 ). Jurnal Komunikasi Indonesia, V, 1-2. https://booksc.xyz/book/75144710/cd1b15

Ketut, Suardika, I., Alberth, Mursalim, iam, Suhartini, L., \& Nikolaus Pasassung. 2020. UsingWhatsAppforteaching a courseontheeducationprofession: Presence, communityandlearning. International Journalof Mobile andBlendedLearning, 12(1), 17-32. https://doi.org/10.4018/IJMBL.2020010102

Larasati, W.,dkk. 2013. Efektivitas Pemanfaatan Aplikasi WhatsApp sebagai Sarana Diskusi Pembelajaran Pada Mahasiswa (UIN Sunan Kalijaga Yogyakarta). https://www.academia.edu/10886930/EfektMarla Mallette, D. B. 2020. onUsing Google Form. By Educators, forEducator, 1- 2. https://booksc.xyz. Diakses pada Senin, tanggal 29 Juni 2020. 
Muri, Yusuf. 2017. Metode Penelitian: Kuantitatif, Kualitatif, dan Penelitian Gabungan. Kencana.

Rayandra, Asyar. 2012. Kreatif Mengembangkan Media Pembelajaran. Jakarta: Gaung Persada Press.

Sugiyono. 2016. Metode Penelitian Kuantitatif. Pandiva Buku

Swita, AH \& Heri, P. (2019). Pemanfaatan Google Classroom Sebagai Media Pembelajaran Online Di Universitas Dian Nuswantoro.Jurnal Ilmiah Ilmu $\begin{array}{lllll}\text { Komunikasi. } & 18 & \text { (2) } & \text { 2 } & 225-233\end{array}$ https://www.researchgate.net/publication/338221952. Diakses pada hari senin, tanggal 29 Juni 2020.

Sumber Internet : https://id.wikipedia.org/wiki/Google_Kelas. Diuduh pada hari Senin, tanggal 29 Juni 2020.

Sumber Internet : https://idcloudhost.com/mengenal-apa-itu-google-classroom-fiturfungsi-dan-keunggulannya/. Diuduh pada hari Senin, tanggal 29 Juni 2020.

Winarso, Bambang, 2015. Apa Itu WhatsApp, Sejarah dan Fitur-fitur Unggulannya?. https://dailysocial.id/post/apa-itu-whatsapp/ Diakses pada hari senin, tanggal 29 Juni 2020. 